\title{
Laboratory diagnosis of human brucellosis in Egypt and persistence of the pathogen following treatment
}

\author{
Ayman Marei ${ }^{1}$, Ghada Boghdadi ${ }^{1}$, Nahla Abdel-Hamed ${ }^{1}$, Rasha Hessin ${ }^{1}$, Theresia Abdoel ${ }^{2}$, \\ Henk Smits ${ }^{2}$, and Fayza Fathey ${ }^{1}$ \\ ${ }^{1}$ Department of Microbiology and Immunology, Faculty of Medicine, Zagazig University, Zagazig, Egypt \\ ${ }^{2}$ KIT Biomedical Research, Royal Tropical Institute / Koninklijk Instituut voor de Tropen (KIT) Amsterdam, The \\ Netherlands
}

\begin{abstract}
Introduction: Brucellosis is a major public health problem in Egypt. The Brucella $\mathrm{IgM} / \mathrm{IgG}$ lateral flow assay was developed as a point-ofcare test for the diagnosis of human brucellosis. The aim of this study was to assess the diagnostic value of the lateral flow assay for use in Egypt.

Methodology: Fifty samples of patients who presented with clinical suspicion of brucellosis over a one-year period were collected. All samples were subjected to the Brucella IgM/IgG lateral flow assay, serum agglutination test (SAT), rose bengal RB Test (RB), 2mercapteoethanol (2-ME), culture and PCR. SAT, 2- ME, culture and PCR were retested after the end of the treatment.

Results: Culture and SAT confirmed the diagnosis of brucellosis in twenty patients. While $90 \%$ of the samples were positive by SAT, only $30 \%$ and $85 \%$ were positive by culture and PCR respectively. The sensitivity of the lateral flow assay calculated for the Brucella IgM/IgG was $95 \%$ and specificity was $97 \%$.

Conclusion: These data show that the lateral flow assay is more suitable for diagnosis of brucellosis in Egypt than culture and SAT. Application of the PCR on serum samples collected during follow-up revealed that the DNA of the pathogen was yet not completely cleared almost 60 days after the start of treatment with doxycycline and ciprofloxacin.
\end{abstract}

Key words: Brucellosis; lateral flow assay; PCR; treatment

J Infect Dev Ctries 2011; 5(11):786-791.

(Received 30 August 2010 - Accepted 17 March 2011)

Copyright (C) 2011 Marei et al. This is an open-access article distributed under the Creative Commons Attribution License, which permits unrestricted use, distribution, and reproduction in any medium, provided the original work is properly cited.

\section{Introduction}

Brucellosis is a serious disease that primarily affects livestock and some wildlife animals, which act as reservoirs for human infection [1]. Brucella is one of the world's major zoonotic pathogens, and is responsible for considerable economic losses as well as human morbidity in endemic areas [2]. Human brucellosis remains endemic in the majority of Middle Eastern countries, accounting for tens of thousands of new cases each year despite continuous efforts to control the disease [3]. Brucellosis is a major public health problem in Egypt especially in the Nile Delta region [4,5]. The clinical features and presentation of human brucellosis overlap with many other infectious and non-infectious diseases [6]. A proper diagnosis is important, as therapeutic failure and relapse, a chronic course, and sometimes severe complications such as bone and joint involvement are characteristic of the disease [7]. The definite diagnosis of brucellosis is made by isolation of the organism from blood samples or other clinical specimens. However, the sensitivity of this technique strongly varies with the stage of illness [8]. Furthermore, culture does not provide a rapid result and many laboratories in endemic areas do not have culture facilities. Therefore, the diagnosis often relies on serologic testing [9].

Serological tests for the diagnosis of human brucellosis such as the rose bengal test (RB), the serum agglutination test (SAT), 2-mercaptoethanol (2-ME) and the enzyme-linked immunosorbent assay (ELISA) have been developed [7]. Due to different levels of exposure, different cut-off levels may apply in countries and areas with a different degree of endemicity. Furthermore, the level of sensitivity of the serological tests differs for the different stages of the disease and in particular a lower sensitivity applies very early in the infection and in patients with chronic disease or experiencing a relapse. Therefore, 
the interpretation of test results may differ and assays require revalidation for use in different countries. These laboratory tests require skilled staff for the standardization of components, procedures, and reading of test results, and furthermore depend on a cool chain for the transportation and storage of reagents. Recently, a simple and rapid point-of-care test for the serodiagnosis of brucellosis, the Brucella $\mathrm{IgM} / \mathrm{IgG}$ immunochromatographic lateral flow assay, was developed that requires no training, expensive or special equipment, or electricity and refrigeration. Therefore, this assay is most suitable for use outside the specialized laboratory and could be used at the bedside or in the field [10].

The optimal treatment regimen for brucellosis is still being debated [11]. Combination therapies consisting of doxycycline plus streptomycin or rifampicin are recommended by the WHO. However, therapeutic failure and the development of persistent diseases as well as the high relapse rate are of concern. Earlier studies using PCR have indicated that the pathogen may persist in the blood of the patient during and following treatment providing a plausible explanation for the suboptimal effect of current treatment regimens [12-14]. Other treatment regimens including treatment with doxycycline and ciprofloxacin have not been demonstrated to be more effective than the WHO recommended regimens [15].

This study was undertaken to evaluate the performances of culture, various serological tests, and PCR in the diagnosis of brucellosis and follow-up after treatment with doxycycline and ciprofloxacin.

\section{Methodology}

\section{Subjects and clinical samples}

Between September 2008 and November 2009, fifty patients suspected with brucellosis (aged 21-65 years old; 31 males and 19 females) were studied at the Department of Microbiology and Immunology of the Faculty of Medicine, Zagazig, Egypt. Written informed consent was obtained from each individual. The diagnosis of brucellosis was based on clinical findings confirmed by either a positive blood culture for Brucella or the presence of specific serum antibodies (SAT titre $\geq 1 / 160$ ). The differential diagnosis for typhoid fever was ruled out by Widal test and blood culture techniques. The duration of signs and symptoms ranged from one to six weeks before hospitalization. Patients with laboratoryconfirmed brucellosis were treated with a combination of doxycycline (200 $\mathrm{mg} /$ day $)$ and ciprofloxacin (500mg, two doses per day) for six weeks. Blood and serum samples were collected on admission and three months later.

\section{Laboratory testing}

For hemoculture, $5 \mathrm{ml}$ of blood were added to 20 $\mathrm{ml}$ of sterile distilled water and $1.5 \mathrm{ml}$ of $4 \%$ sodium citrate. The contents were gently mixed, and the tube was centrifuged at $2,000 \mathrm{xg}$ for 30 minutes. The supernatant was discarded, and the sediment was inoculated onto brain heart infusion agar plates and incubated at $37^{\circ} \mathrm{C}$ for 15 days with a $5 \% \mathrm{CO}_{2}$ atmosphere [16]. Brucella isolates were identified with Gram stain and conventional biochemical testing.

For serology, the RB test was performed according to standard procedures [17] with antigen obtained from Spinreact, Girona, Spain. The SAT was performed on serial serum dilutions of $1 / 40$ to 1/1280 by using Brucella abortus antigen obtained from (Linear Chemicals, Barcelona, Spain). SAT was considered positive when a titre of $\geq 1 / 160$ was obtained. The 2-ME test was performed in the same manner as SAT test except that sera were diluted in PBS containing $0.1 \mathrm{M}$ 2-ME to eliminate agglutinating $\operatorname{IgM}$ antibodies by breaking the disulfide bonds and depolymerising of the $\operatorname{IgM}$. The 2-ME test was considered positive for IgM when a reduction in titre compared with SAT was observed and positive for $\operatorname{IgG}$ when a titre $\geq 1 / 180$ was obtained [18].

For the lateral flow assay, $5 \mu \mathrm{l}$ of serum followed by $130 \mu 1$ of running fluid were added to the sample application pad in the sample well of the plastic assay device (Royal Tropical Institute, Amsterdam, The Netherlands) [19]. The assay was read after 10 to 15 minutes by visual inspection for staining of the test and control lines in the assay window of the device. The test line may stain at different intensities and was subjectively rated $1+$ when staining was weak, $2+$ when staining was moderate, $3+$ when staining was strong, and $4+$ when staining was very strong. The test was scored negative when only staining of the control was observed.

For PCR analysis, DNA was extracted from 200 $\mu 1$ of blood using QIAamp DNA Blood Mini Kit (Qiagen, QIAGEN GmbH, Hilden, Germany) according to the manufacturer's instructions. DNA was amplified using primers B4/B5 which amplified a 223-bp fragment present on a gene encoding a 31$\mathrm{kDa} B$. abortus antigen [20]. The amplification was performed in a total volume of $25 \mu$ l by using ReadyTo-Go PCR beads (Pharmacia Biotech, 
Table 1. Diagnostic sensitivity and specificity of different serological tests for initial serum samples from patients with confirmed brucellosis

\begin{tabular}{|l|c|c|c|}
\hline Assay & $\begin{array}{c}\text { No. of positive samples } \\
\text { from patients with } \\
\text { confirmed brucellosis } \\
(\mathbf{n = 2 0})\end{array}$ & $\begin{array}{c}\text { Sensitivity \% } \\
(\mathbf{9 5 \%} \mathbf{~ C I} \mathbf{1})\end{array}$ & $\begin{array}{c}\text { Specificity \% } \\
(\mathbf{9 5 \%} \mathbf{C I})\end{array}$ \\
\hline RB & 20 & $100(86-100)$ & $100(86-100)$ \\
\hline SAT $\geq \mathbf{1 / 1 6 0}$ & 18 & $90(67-98)$ & $100(86-100)$ \\
\hline $\mathbf{2 - M E ~} \geq \mathbf{1 / 8 0}$ & 13 & $65(41-84)$ & $100(86-100)$ \\
\hline IgM flow & 14 & $70(46-87)$ & $97(81-100)$ \\
\hline IgG flow & 13 & $65(41-84)$ & $97(81-100)$ \\
\hline IgM + IgG flow & 19 & $95(73-100)$ & $97(81-100)$ \\
\hline PCR & 17 & $85(61-97)$ & $97(81-100)$ \\
\hline
\end{tabular}

${ }^{1} \mathrm{CI}=$ Confidence interval

Buckinghamshire, UK). The concentration of each primer was $0.5 \mu \mathrm{M}$. After an initial denaturation step at $93^{\circ} \mathrm{C}$ for 5 minutes, 40 amplification cycles were performed as follows: denaturation at $90^{\circ} \mathrm{C}$, annealing at $60^{\circ} \mathrm{C}$ and extension at $72^{\circ} \mathrm{C}$ (each for 1 minute) and a final 10 minute extension step at $72^{\circ} \mathrm{C}$.

\section{Statistics}

For statistical analysis we used the parametric paired single-sided Student's t-test.

The threshold below the calculated p-value was chosen at the 0.05 level for statistical significance. Assay sensitivity was calculated using hemoculturepositive and/or SAT positive (titre $\geq 1 / 160$ ) as the reference standard.

\section{Results}

Twenty patients (40\%) were diagnosed with brucellosis. Six patients were diagnosed with brucellosis based on a positive blood culture and 14 patients were diagnosed with brucellosis based on the presence of serum antibodies reactive in the (SAT titre $\geq 1 / 160$ ). These brucellosis patients included 13 males and 7 females and their mean age was $32.9 \pm$ 8.11 years; (range 21 to 63 years). Two of the patients with culture-proven brucellosis had an insignificant SAT titre of $1 / 80$. The results of the various diagnostic assays for the samples collected at first diagnosis indicate a sensitivity of $100 \%$ for RB, $90 \%$ for the SAT, $65 \%$ for the $2-\mathrm{ME}, 95 \%$ for the lateral flow assay and $85 \%$ for the PCR (Table 1). The mean titre in the SAT was 1/320 and an average of 2.7-fold reduction in titre was observed in the 2ME test. Reactivity in the lateral flow assay for the patients with confirmed brucellosis indicated the presence of only specific IgM antibodies in the serum of six cases, the presence of specific IgM and $\operatorname{IgG}$ antibodies in eight cases and the presence of only specific IgG antibodies in five cases. Twelve of the 14 IgM flow assay positive patients showed a reduction in titre in the 2-ME test. Notably, two patients with culture-confirmed brucellosis with a non-significant SAT titre of $1 / 80$ reacted positive in the IgM lateral flow assay and the PCR.

One of the samples from a patient with febrile syndrome involving a differential diagnosis with brucellosis that was culture negative for brucellosis and tested negative by the SAT (1/80) was positive by the RB, IgM and IgG lateral flow and PCR assays. Based on these results, the specificity of the RB, lateral flow and PCR assays were calculated to be 97\% (Table 1). This patient was diagnosed with typhoid fever. Another blood sample that was collected two months later showed a SAT titre of $1 / 320$ and positive blood culture for brucellosis. The possible explanation is that this patient experienced a relapse of past infection with Brucella.

A follow-up sample collected six weeks after the conclusion of treatment was obtained from 13 patients with confirmed brucellosis. Significant SAT titres $(\geq 1 / 60)$ were measured in the follow-up serum of six patients (Table 2). A positive result in the PCR for the follow-up blood samples was obtained for four patients. At follow-up, SAT titre $(\geq 1 / 60)$ was seen in $23 \%$ of the cases with $8 \%$ reduction compared with the baseline (Table 3). All patients with a positive PCR at follow-up tested seropositive in the SAT. In the two patients with initial PCR 
Table 2. Assay results at baseline and at follow-up

\begin{tabular}{|c|c|c|}
\hline \multirow[t]{2}{*}{ Stage } & \multicolumn{2}{|c|}{ No. positive in the following assays (percentage positive) } \\
\hline & $\mathrm{SAT} \geq \mathbf{1 / 1 6 0}$ & PCR \\
\hline First diagnosis & $12(92 \%)$ & $11(85 \%)$ \\
\hline Follow up ${ }^{1}$ & $6(46 \%)$ & $4(31 \%)$ \\
\hline
\end{tabular}

${ }^{1} 6$ weeks after conclusion of treatment

Table 3. Evolution of SAT following treatment

\begin{tabular}{|c|c|c|c|c|c|c|}
\hline SAT & $1 / 40$ & $1 / 80$ & $1 / 160$ & $1 / 320$ & $1 / 640$ & $1 / 1280$ \\
\hline First diagnosis & & $1(8 \%)$ & $4(31 \%)$ & $4(31 \%)$ & $2(15 \%)$ & $2(15 \%)$ \\
\hline Follow up ${ }^{T}$ & $2(15 \%)$ & $5(38 \%)$ & $3(23 \%)$ & $2(15 \%)$ & $1(8 \%)$ & \\
\hline
\end{tabular}

${ }^{1} 6$ weeks after conclusion of treatment

negative samples, the post treatment sample was PCR negative as well. One patient for whom the PCR remained positive at the end of treatment had a confirmed relapse by a positive blood culture and had a significant SAT titre of 1/640.

\section{Discussion}

The Brucella $\mathrm{IgM} / \mathrm{IgG}$ flow assay is a rapid test for the confirmation of brucellosis. The assay is userfriendly and is easy to read. Furthermore, the assay components are individually wrapped and may be stored at ambient temperature without the need for refrigeration. The assay may be performed on a drop of blood collected by finger prick and may be used at the bedside or in the field. This could be an important aspect in countries such as Egypt where the disease is widely spread. Furthermore, our results are in agreement with the high sensitivity and specificity observed for the flow assay by earlier reports from Spain [19], Turkey [21,22], and Kazakhstan [21]. Therefore, in the absence of the laboratory support, the flow assay may be used for the confirmation of brucellosis in febrile patients with clinical suspicion of brucellosis by testing a drop of blood collected by finger prick. The results of the flow assay may also be used to determine the stages of the brucellosis. The detection of specific IgM in the flow assay is consistent with acute disease, while as the disease progresses to subacute and persistent stages, specific IgG antibodies become more abundant [21]. The results of the flow assay closely correlated with the differentiation between specific $\operatorname{IgM}$ and $\mathrm{IgG}$ antibodies in the 2-ME test.

Two patients that showed a SAT of $1 / 80$ had a positive blood culture and tested positive in the PCR and for specific IgM antibodies in the lateral flow assay. These data highlight the importance of using more than one test in diagnosis of brucellosis, especially in endemic areas where active brucellosis cannot be excluded in a patient with SAT lower than 1/160 [24]. In addition, SAT suffers from high false negative rates in complicated and chronic cases [6]. Moreover, SAT false negative results may occur in patients with very recent infection or those who have blocking antibodies in their serum. The flow assays detected five out of six individuals that were hemoculture-positive. Of these five patients, two serum samples showed SAT of $1 / 80$. This result agreed with that from a study from Turkey [21] which showed that several culture-confirmed patients with low SAT were clearly positive in the lateral flow assay.

PCR confirmed the diagnosis of brucellosis in $85 \%$ of the cases indicating that PCR could be an important adjunct for the diagnosis of brucellosis [2527]. However, PCR requires a sophisticated laboratory and highly skilled staff. Therefore, the use of the RB, the flow assay, or a combination of the two tests appears a good choice for countries such as Egypt where brucellosis is endemic but laboratory support is not readily available.

Treatment failure and relapsing disease are common in brucellosis. Earlier PCR studies indicated that the pathogen may persist in the blood of patients during and after the end of treatment with the standard combination therapies consisting of doxycycline with rifampicin and doxycycline with streptomycin, which have been recommended by the WHO [12-13,25]. In our study, we found that the pathogen persisted more than three months in patients treated with doxycyline and ciprofloxacine. Moreover, Brucella was isolated from the blood of one of these PCR positive patients while experiencing a relapse. In addition, the equal efficacy in terms of therapeutic response and relapse rate for the treatment of brucellosis with doxycycline plus 
rifampicin, doxycyline plus ciprofloxacin, or ciprofloxacin plus rifampicin was observed [15]. These observations support the view that better treatment protocols for brucellosis are still needed [11]. In our study, Brucella DNA was detected in three samples of clinically cured patients (negative blood culture and no significant SAT) during followup. This means that clinical recovery does not relate to the clearance of the organism and stresses the point that the presence of DNA may not be denoting active disease that requires treatment.

In conclusion, the flow assay showed concordant results with SAT and PCR tests and can be used reliably for the diagnosis of brucellosis. Moreover, the simplicity of the $\operatorname{IgM} / \mathrm{IgG}$ flow assay makes it the most suitable complementary test for diagnosis of human brucellosis and may be used as a rapid diagnostic test in combination with the RB as a simple screening test. Finally, we demonstrated that relapse and persistent disease after treatment with doxycyline and ciproforxacin may be caused by persistence of the pathogen in the blood of the patient. Thus the detection of Brucella DNA by PCR in treated patients may not always indicate active infection but the persistence of the pathogen in the blood following treatment may increase the risk of relapse.

\section{References}

1. Corbel MJ (1997) Brucellosis: an overview. Emerg Infect Dis 3: 213-221.

2. Boschiroli ML, Foulongne V, O'Callaghan D (2001) Brucellosis: a worldwide zoonosis. Curr Opin Microbiol 4: 58-64.

3. Pappas G and Memish ZA (2007) Brucellosis in the Middle East: a persistent medical, socioeconomic and political issue. J Chemother 19: 243-248.

4. Afifi S, Earhart K, Azab MA, Youssef FG, El Sakka H, Wasfy M, Mansour H, El Oun S, Rakha M, Mahoney F (2005) Hospital-based surveillance for acute febrile illness in Egypt: a focus on community-acquired bloodstream infections. Am J Trop Med Hyg 73: 392-399.

5. Samaha H, Mohamed TR, Khoudair RM, Ashour HM (2009) Serodiagnosis of brucellosis in cattle and humans in Egypt. Immunobiology 214: 223-226.

6. Araj GF (1999) Human brucellosis: a classical infectious disease with persistent diagnostic challenges. Clin Lab Sci 12: 207-212.

7. Al Dahouk S, Tomaso $H$, Nockler $K$, Neubauer $H$, Frangoulidis D (2003) Laboratory-based diagnosis of brucellosis--a review of the literature. Part II: serological tests for brucellosis. Clin Lab 49: 577-589.

8. Espinosa BJ, Chacaltana J, Mulder M, Franco MP, Blazes DL, Gilman RH, Smits HL, Hall ER (2009) Comparison of culture techniques at different stages of brucellosis. Am J Trop Med Hyg 80: 625-627.
9. Young EJ (1995) An overview of human brucellosis. Clin Infect Dis 21: 283-289; quiz 290.

10. Franco MP, Mulder M, Gilman RH, Smits HL (2007) Human brucellosis. Lancet Infect Dis 7: 775-786.

11. Ariza J, Bosilkovski M, Cascio A, Colmenero JD, Corbel MJ, Falagas ME, Memish ZA, Roushan MR, Rubinstein E, Sipsas NV, Solera J, Young EJ, Pappas G (2007) Perspectives for the treatment of brucellosis in the $21 \mathrm{st}$ century: the Ioannina recommendations. PLoS Med 4, e317.

12. Maas KS, Mendez M, Zavaleta M, Manrique J, Franco MP, Mulder M, Bonifacio N, Castaneda ML, Chacaltana J, Yagui E, Gilman RH, Guillen A, Blazes DL, Espinosa B, Hall E, Abdoel TH, Smits HL (2007) Evaluation of brucellosis by PCR and persistence after treatment in patients returning to the hospital for follow-up. Am J Trop Med Hyg 76: 698702.

13. Mitka S, Anetakis C, Souliou E, Diza E, Kansouzidou A (2007) Evaluation of different PCR assays for early detection of acute and relapsing brucellosis in humans in comparison with conventional methods. J Clin Microbiol 45: 1211-1218.

14. Navarro E, Segura JC, Castano MJ, Solera J (2006) Use of real-time quantitative polymerase chain reaction to monitor the evolution of Brucella melitensis DNA load during therapy and post-therapy follow-up in patients with brucellosis. Clin Infect Dis 42: 1266-1273.

15. Keramat F, Ranjbar M, Mamani M, Hashemi SH, Zeraati F (2009) A comparative trial of three therapeutic regimens: ciprofloxacin-rifampin, ciprofloxacin-doxycycline and doxycycline-rifampin in the treatment of brucellosis. Trop Doct 39: 207-210.

16. Mantur BG and Mangalgi SS (2004) Evaluation of conventional Castaneda and lysis centrifugation blood culture techniques for diagnosis of human Brucellosis. J Clin Microbiol 42: 4327-4328.

17. Morgan WJ, Mackinnon DJ, Lawson JR, Cullen GA (1969) The rose bengal plate agglutination test in the diagnosis of brucellosis. Vet Rec 85: 636-641.

18. Klein GC and Behan KA (1981) Determination of brucella immunoglobulin $\mathrm{G}$ agglutinating antibody titer with dithiothreitol. J Clin Microbiol 14: 24-25.

19. Smits HL, Abdoel TH, Solera J, Clavijo E, Diaz R (2003) Immunochromatographic Brucella-specific immunoglobulin $\mathrm{M}$ and $\mathrm{G}$ lateral flow assays for rapid serodiagnosis of human brucellosis. Clin Diagn Lab Immunol 10: 1141-1146.

20. Baily GG, Krahn JB, Drasar BS, Stoker NG (1992) Detection of Brucella melitensis and Brucella abortus by DNA amplification. J Trop Med Hyg 95: 271-275.

21. Irmak H, Buzgan T, Evirgen O, Akdeniz H, Demiroz AP, Abdoel TH, Smits HL (2004) Use of the Brucella IgM and IgG flow assays in the serodiagnosis of human brucellosis in an area endemic for brucellosis. Am J Trop Med Hyg 70: 688-694.

22. Zeytinoglu A, Turhan A, Altuglu I, Bilgic A, Abdoel TH, Smits HL (2006) Comparison of Brucella immunoglobulin $M$ and $G$ flow assays with serum agglutination and 2mercaptoethanol tests in the diagnosis of brucellosis. Clin Chem Lab Med 44: 180-184.

23. Mizanbayeva S, Smits HL, Zhalilova K, Abdoel TH, Kozakov S, Ospanov KS, Elzer PH, Douglas JT (2009) The evaluation of a user-friendly lateral flow assay for the serodiagnosis of human brucellosis in Kazakhstan. Diagn Microbiol Infect Dis 65: 14-20. 
24. Cooper CW (1992) Prevalence of antibody to Brucella in asymptomatic well individuals in Saudi Arabia. J Trop Med Hyg 95: 140-142.

25. Morata P, Queipo-Ortuno MI, Reguera JM, Garcia-Ordonez MA, Pichardo C, Colmenero JD (1999) Posttreatment follow-Up of brucellosis by PCR assay. J Clin Microbiol 37: 4163-4166.

26. Bricker BJ (2002) PCR as a diagnostic tool for brucellosis. Vet Microbiol 90: 435-446.

27. Navarro E, Casao MA, Solera J (2004) Diagnosis of human brucellosis using PCR. Expert Rev Mol Diagn 4: 115-123.

\section{Corresponding author}

Dr. Ayman Marei

Department of Microbiology and Immunology

Faculty of Medicine

Zagazig University

Zagazig, Egypt

Telephone: +20129255205

Fax: +2(0)552635391

Email: ammarei@zu.edu.eg

Conflict of interests: No conflict of interests is declared 